\title{
COVID-19 during pregnancy and its impacts on perinatal health
}

\author{
Sertaç Esin ${ }^{1}$ (D) , Aslı Azemi' (D), Oluş Api ${ }^{2}$ (D), Murat Yayla ${ }^{3}$ (ID) , Cihat Şen ${ }^{4}$ \\ ${ }^{1}$ Department of Perinatal Medicine, Faculty of Medicine, Baskent University, Ankara, Turkey \\ ${ }^{2}$ Foundation of Perinatal Medicine, \& Department of Perinatal Medicine, American Hospital, Istanbul, Turkey \\ ${ }^{3}$ Department of Perinatal Medicine, Acıbadem International Hospital, Istanbul, Turkey \\ ${ }^{4}$ Foundation of Perinatal Medicine, \& Department of Perinatal Medicine, Memorial Bahçelievler Hospital, Istanbul, Turkey
}

\begin{abstract}
In this review, we reviewed current literature on COVID-19 infection during pregnancy and provided up-to-date information and community/society recommendations. Although it has previous examples such as SARS and MERS and the infection findings appeared at an earlier period and have become known in China, the infection could not be limited and spread worldwide. Until June 8, 2020, a total of 6.8 million cases were reported and 397,000 cases died. As of the same date, the total case number in Turkey is 171,000 and total number of death is 4711. COVID-19 virus spread by droplets and its incubation period varies between 2 and 14 days. The rate of asymptomatic cases is $42 \%$ in non-pregnant patients while it is $44-89 \%$ in pregnant women. The disease progresses with mildmedium severity in about $80 \%$ of the patients, and it recovers by itself. A total of 17 maternal death cases has been reported. Although vertical transmission risk is very low according to a study investigating 265 pregnant women, there are cases showing fetal vertical transmission and we reviewed such cases in detail in this review.
\end{abstract}

Keywords: COVID-19, SARS, MERS, pregnancy.

\section{Introduction}

The mysterious pneumonia cases appeared in December 2019 attracted the attention of the world to China, and when it became a pandemic, each country started to monitor their situation and case numbers. While the first source of the new member of Coronavirus family, which is later called COVID-19 virus or SARS-Cov-2 or 2019-

\section{Özet: Gebelikte COVID-19 ve perinatal sağlık üzerine} etkileri

Bu derlemede gebelikte COVID-19 enfeksiyonu konusunda güncel literatür gözden geçirilecek, güncel gelişmeler ve cemiyet/dernek önerilerine yer verilecektir. Önceden SARS ve MERS gibi örnekler bulunmasına ve Çin'deki enfeksiyon bulgularının daha erken dönemde ortaya çıması ve bilinir hale gelmesine rağmen enfeksiyon sınırlı kalmamış ve tüm dünyaya hızlıca yayılmıştır. 8 Haziran 2020 tarihine kadar dünyada toplam 6.8 milyon vaka bildirilmiş ve 397.000 ölüm gerçekleşmiştir. Yine aynı tarih itibari ile Türkiye'de toplam vaka sayısı 171.000 , ölüm sayısı ise 4711 'dir. COVID-19 virüsü damlacık yolu ile yayılmaktadır ve inkübasyon periyodu 2-14 gün arasında değişmektedir. Asemptomatik hastalık oranı gebe olmayan hastalarda \%42'lerde iken gebelerde \%44-89'dir. Yaklaş1k $\% 80$ hastada hastalık hafif-orta şiddette seyretmekte ve kendiliğinden iyileşmektedir. Toplam 17 maternal ölüm bildirilmiştir. 265 gebenin incelendiği çalışmaya göre vertikal geçiş riski son derece az olmakla birlikte fetal vertikal geçiş lehine vakalar mevcuttur ve bu derlemede ayrıntılı olarak incelenecektir.

Anahtar sözcükler: COVID-19, SARS, MERS, gebelik.

$\mathrm{cCoV}$, is not known clearly, it was claimed that it is associated with a seafood market in Wuhan, the capital city of China's Hubei province. ${ }^{[1]}$ The case numbers increased gradually, and the new cases were seen in Thailand, Japan, Hong Kong, Taiwan, South Korea and England at the end of January 2020.

COVID-19 virus show similarities with SARS (severe acute respiratory syndrome) and MERS (Middle

Correspondence: Sertaç Esin, MD. Department of Perinatal Medicine, Faculty of Medicine, Başkent University, Ankara, Turkey.

e-mail: sertacesin@gmail.com / Received: June 8, 2020; Accepted: June 13, 2020

Please cite this article as: Esin S, Azemi A, Api O, Yayla M, Şen C. COVID-19 during pregnancy and its impacts on perinatal health. Perinatal Journal 2020;28(2):127-141. doi:10.2399/prn.20.0282012 
East respiratory syndrome) viruses, which are the other members of Coronavirus family. While there were 6 known types of Coronavirus until December 2019, this number reached 7 with the appearance of COVID-19. Non-SARS and non-MERS 4 members (HKU1, OC43, 229E, NL63) are associated with seasonal common cold, and they are responsible for $10 \%$ of non-influenza seasonal airway disease. MERS appeared in Saudi Arabia in 2012, and its R0 rate is less than 1 with a case-fatality rate of $34.4 \%$ (CFR) (858/2494). ${ }^{[2,3]} \mathrm{R} 0$ is an index showing how contagious is an infection and the average number of people who will contract an infection from one person. SARS pandemic was seen in 2002-2003, and its R0 rate was 2-4 with a case-fatality rate of $10.5 \%$ $(774 / 8098) .{ }^{[4,5]}$ While case-fatality rate is usually $0.5 \%$ in the seasonal flu, its R0 rate is $1.2-1.6 .^{[6-8]}$ The general characteristics of Coronavirus types and influenza H1N1 are shown in the Table $\mathbf{1 .}$

The mortality rate of COVID-19 is associated with the age of patient and coexisting diseases, and it varies across countries. The overall mortality rate in China was reported $2.3 \%$ in the beginning, but it may increase up to $14.8 \%$ in cases over 80 years old. The mortality rates may increase up to $6 \%$ with coexisting hypertension, $7.3 \%$ with coexisting diabetes and $6.3 \%$ with coexisting chronic respiratory pathologies. ${ }^{[9]}$ However, it is accepted that the mortality rate of COVID-19 is higher than influenza.

Although it has previous examples such as SARS and MERS and the infection findings appeared at an earlier period and have become known in China, the infection could not be limited and spread worldwide. World Health Organization (WHO) held a meeting on January 22, 2020 and the Organization did not accept that COVID-19 infection was an international public health emergency, and the pandemic decision could only be made on March 11 by WHO. While the data of WHO on February 3 showed that there were 17,238 cases and 361 deaths in China, the number of diagnosed cases exceeded 3 million and 208,000 cases died as of April 27. In June 8, 2020, a total of 6.8 million cases were reported in the world and 397,000 cases died. As of the same date, total case number was 171,000 and death number was 4711 in Turkey.

COVID-19 virus spread by droplets. ${ }^{[10]}$ Its incubation period varies between 2 and 14 days (the mean period is 5.2 days). ${ }^{[1,11]}$ It is known that the course of disease can be asymptomatic. While asymptomatic infection rate is
Table 1. Coronavirus types and the general characteristics of influenza H1N1.

\begin{tabular}{lccc} 
& Genome & Case-fatality rate & R0 \\
MERS & RNA & $27.3-34.4 \%^{[22.98]}$ & $<1^{[3]}$ \\
SARS-CoV & RNA & $10.5-25 \%^{[1,2]}$ & $2-4^{[5]}$ \\
SARS-CoV-2 & RNA & $1.3-3.85 \%^{[99,100]}$ & $2-2.5 \%^{[2]}$ \\
Influenza H1N1 & RNA & $0.5 \%$ & $1.2-1.6^{[6-8]}$ \\
\hline
\end{tabular}

about $42 \%$ in non-pregnant patients, ${ }^{[12]}$ it was reported between $44 \%$ and $89 \%$ in pregnant women. ${ }^{[13-15]}$ The disease progresses with mild-medium severity in about $80 \%$ of the patients, and it recovers by itself. It is severe in $13.8 \%$ of the patients, and at a critical level in $6.8 \%$ of the patients. ${ }^{[16]}$ In this review, we reviewed current literature on COVID-19 infection during pregnancy and provided up-to-date information and community/society recommendations.

\section{Pregnancy and Pneumonia}

Independently of COVID-19, pneumonia is one of the most important reasons of morbidity and mortality in pregnant women and the most common non-obstetric infection reason during pregnancy. ${ }^{[16]}$ Intensive care treatment may be required in $25 \%$ of patients due to the pneumonia. ${ }^{[17]}$ When compared to bacterial pneumonia cases, morbidity and mortality rates are higher in viral pneumonia cases. ${ }^{[18]}$ Premature rupture of membranes (PRM), preterm labor, stillbirth, fetal growth restriction and neonatal death are the most important complications of pneumonia during pregnancy. ${ }^{[17,19,20]}$

\section{The Relationship Between Pregnancy and SARS, MERS and Influenza}

Before investigating the relationship between pregnancy and COVID-19, it would be better to assess the relationship between pregnancy and other Coronavirus types and influenza virus, because the lessons that can be taken from these viruses may guide us with the fight with this new and young member of the family.

In terms of the course of other Coronavirus types during pregnancy, which cause significant pandemic, except COVID-19 infection (Table 2), it was reported that the rate of hospitalization in the intensive care unit due to SARS-CoV infection in pregnant women during SARS pandemic was $50 \% .{ }^{[8]}$ It was observed that SARS- 
Table 2. Coronavirus types and gestational complications.

\begin{tabular}{|c|c|c|c|c|c|c|c|c|}
\hline & $\begin{array}{l}\text { Case-fatality } \\
\text { rate }\end{array}$ & $\begin{array}{c}\text { Rate of } \\
\text { hospitalization } \\
\text { at intensive care }\end{array}$ & $\begin{array}{c}\text { Preterm labor } \\
\text { before } 37 \\
\text { weeks }\end{array}$ & $\begin{array}{c}\text { Preterm labor } \\
\text { before } 34 \\
\text { weeks }\end{array}$ & Preeclampsia & $\begin{array}{c}\text { Preterm } \\
\text { rupture of } \\
\text { membranes }\end{array}$ & $\begin{array}{l}\text { Intrauterine } \\
\text { growth } \\
\text { restriction (IUGR) }\end{array}$ & $\begin{array}{l}\text { Delivery by } \\
\text { cesarean } \\
\text { section }\end{array}$ \\
\hline MERS & $27.3-34.4 \%^{[22.98]}$ & $63.6 \%^{122]}$ & $0 \%{ }^{[41]}$ & $32.1 \%^{[41]}$ & $19.1 \%^{[4]]}$ & $0 \%{ }^{[41]}$ & $0 \%{ }^{[41]}$ & $61.8 \%^{[4]]}$ \\
\hline SARS-CoV & $10.5-25 \%^{[4,21]}$ & $50 \%^{[21]}$ & $15.3 \%^{[41]}$ & $28.9 \%^{[41]}$ & $0 \%{ }^{[4]]}$ & $50 \%^{[41]}$ & $18.5-40 \% \%^{[21,41]}$ & $72.2 \%^{[4]]}$ \\
\hline SARS-CoV-2 & $1.3-3.85 \%^{199,100]}$ & $5-12 \%^{[101,102]}$ & $15.2-80 \%{ }^{[21,103]}$ & $15.3 \%^{[4]]}$ & $13.5 \%^{[4]]}$ & $18.7 \%^{[41]}$ & $0 \%{ }^{[41]}$ & $70-78.1 \%^{[103,104]}$ \\
\hline
\end{tabular}

$\mathrm{CoV}$ infection during pregnancy has negative impacts on gestational outcomes. Abortion was reported in $57 \%$ of the women who had SARS-CoV infection during the first trimester, and fetal growth restriction in $40 \%$ of them and preterm labor in $80 \%$ of them during the second trimester. ${ }^{[21]}$

In MERS pandemic, the rate of hospitalization in the intensive care unit due to MERS-CoV infection in the pregnant women was reported $63.6 \%$. It was seen that the poor gestational outcomes increased in MERS infection during pregnancy (91\%) similar to SARS-CoV infection, and $55 \%$ of the newborns required hospitalization in the newborn intensive care unit. ${ }^{[2]}$ No maternal-fetal vertical transmission was observed in SARS and MERS pandemics. ${ }^{[2]]}$

When it comes to influenza which is another factor for respiratory tract infection, 1918 Spanish flu, 1956 Asian flu and 2009-2010 influenza pandemics are the significant ones. In the influenza pandemic called Spanish flu which occurred in the winter of 1918-1919 causing 500 million people to contract the disease and $40-70$ million people to die, the mortality rate is $27 \%$ in the pregnant women and this rate reached $50 \%$ when the disease was complicated with pneumonia. ${ }^{[2]}$

In the pandemic that appeared in Asia in 1957 due to influenza A (H2N2) and caused 1.1 million people to die of which 116,000 were in the United States of America (USA), $50 \%$ of the death cases among women in reproductive period were pregnant. ${ }^{[25]}$ In the spring of 2009, the pandemic which appeared due to influenza H1N1 which was also called swine flu was first seen in the USA and spread worldwide rapidly. According to the data of CDC, it is estimated that 151,700 575,400 people died in the year that $\mathrm{H} 1 \mathrm{~N} 1$ pandemic appeared. Similar to other flu viruses, the complication rates in this virus were also higher in pregnant women. Although only $1 \%$ of the US population consists of pregnant women, $\mathrm{H} 1 \mathrm{~N} 1$ virus infection during pregnancy is responsible for $6.3 \%$ of pandemic-related hospitalization rates, $5.9 \%$ of hospitalization in the intensive care unit and $5.7 \%$ of death cases. ${ }^{[8,26]}$ The severity of disease increased with the progress of the week of gestation. The most severe cases were in the third trimester of gestation. ${ }^{[27]}$ The death rate of H1N1 pandemic during pregnancy is between $8.2 \%$ and $9 \%$ and the rate decreases when the antiviral treatment is initiated within the first 3 days of infection. ${ }^{[28]}$

It was found in significant studies including broad patient groups that the influenza infection during pregnancy had a severe course also during non-pandemic periods compared to non-pregnant population and required more hospitalization. ${ }^{[2]}$ In coexisting morbidity cases such as chronic heart and lung disease, diabetes, chronic kidney, cancer and suppressed immunization during pregnancy, this risk increases at least 3 times. The severity of H1N1 virus infection in pregnancy during non-pandemic periods also increases as the week of gestation proceeds and the most severe cases are seen during the third trimester of gestation. ${ }^{[27]}$

\section{COVID-19 and Pregnancy}

When it comes to COVID-19 infection during pregnancy, COVID-19 was first reported in China as it appeared in this country first. The first study included the pregnant women population in Wuhan and 9 pregnant women who were diagnosed between January 20, 2020 and January 31, 2020 were reported..$^{[30]}$ The second manuscript is on "pregnant patient population in Hubei" and it reported the results of 9 patients and 10 newborns. ${ }^{[31]}$ The clinical courses of these 19 pregnant women in total in these first 2 studies are similar to the non-pregnant patients; all pregnant women had pneumonia and there were typical infiltrates in their lung CTs. None of the 
pregnant women needed mechanical ventilation and no death was reported. A total of 5 patients had PRM. Seventeen of the patients in these 2 studies delivered by cesarean section while 2 of them delivered vaginally. No infection was found in the newborns and placentas of these patients. While elevated cardiac enzymes were detected in a newborn in Wuhan group, DIC-related death occurred in a baby born at 34.5 weeks of gestation in Hubei group; however, COVID-19 infection was not found in this newborn.

After these initial reports, COVID-19 infection was reported in more pregnancies. In the review of 6 studies conducted by Della Gatta et al. in April 2020, the authors reviewed 51 pregnant patients. ${ }^{[32]}$ The diagnosis was established by qRT-PCT in 50 of these 51 patients, one patient could be diagnosed as it was consistent with clinical COVID-19 and other potential factors were ruled out. In this review, the median maternal age was 30 , median week of gestation during diagnosis was 36 , median week of labor was 36.5 , and $39 \%$ of the patients underwent preterm labor. The median of the period from the development of symptoms up to labor is 2 days. The symptoms developed after labor in 3 patients. During admission, $48 \%$ of the patients had fever and $46 \%$ of them had dry cough. Other rare symptoms are sore throat, dyspnea, fatigue- malaise, myalgia, diarrhea and cholecystitis. Pregestational comorbidities such as hypertension, diabetes or cardiovascular diseases were not reported. Gestational hypertension was seen in one patient, preeclampsia in patient and influenza infection coexisting with COVID-19 in one patient. Two of the pregnant women were at the second trimester and 49 of them were at the third trimester during the diagnosis. The cesarean section was performed in 46 of 48 patients whose pregnancy were terminated. PRM developed in $26 \%$ of the pregnant women. Severe pneumonia requiring the use of ECMO developed in one of the pregnant women and stillbirth occurred. While there were typical findings in the lung tomography scan in 22 patients, lung tomography results of one patient were normal. Of the newborns, 48 had good health, but one newborn was stillbirth as stated above. In addition, one baby which was born at 34.5 weeks of gestation died on 9th day, but the test result of COVID-19 was negative. No fetal vertical transmission was observed in this review.

The review in which 108 COVID-19 positive pregnant women were reviewed was published by Zaigham and Andersson. ${ }^{[3]}$ Of the patients, $68 \%$ had fever and
$34 \%$ had fever. Lymphocytopenia was found in 59\% of the patients, and elevated CRP in $59 \%$ of the patients. $91 \%$ of the pregnant women delivered by the cesarean section and three pregnant women required intensive care, but maternal mortality was not observed. Stillbirth was observed in one baby and neonatal death in one baby.

Afterwards, one of the biggest series was published in China. In the study evaluating 116 pregnant women with COVID-19 infection, the authors found severe pneumonia in 8 patients, but did not observe any maternal death. Eight of 116 pregnant women were detected in the first trimester or early second trimester and abortion was observed in one of these pregnant women $(1 / 8 ; 12.5 \%)$. Preterm labor before 37 weeks of gestation was observed in 6 patients $(6.1 \%)$, negative result was obtained in 86 newborns who underwent PCR test. ${ }^{[34]}$

A total of 324 patients were evaluated in the systematic review of 9 case series and 15 case reports in May $2020 .^{[35]}$ Of these patients, $211(71.5 \%)$ were diagnosed by laboratory findings and $84(28.5 \%)$ by clinical findings. The most common symptoms during the admission of pregnant patients were fever, cough, respiratory distress, fatigue and myalgia. Severe pneumonia was found in $0-14 \%$ of the patients who required intensive care. PCR tests were conducted on the vaginal secretion of 6 patients and on breast milk of 22 patients, and all results were reported negative. Spontaneous abortion was reported in 4 patients. The weeks of labor were $28-41$ and $74.2 \%$ of them underwent the cesarean section. The authors reported that the preeclampsia risk did not increase in the pregnant women with COVID-19. One third of the newborns were followed up in the intensive care. Neonatal asphyxia was observed in one of the babies and neonatal death in one baby. According to the study published in Sweden in May 2020, the risk of hospitalization in the intensive care during pregnancy or postpartum period was found higher than the non-pregnant women who are at similar ages. ${ }^{[36]}$

COVID-19 binds to cells via ACE-2 receptor. ACE2 RNA expression is very low in the placenta during 6-14 weeks of gestation, and therefore it was asserted that the risk of placental transmission during first trimester is low. ${ }^{[37,38]}$ However, it was reported that pregnancy loss may be observed due to maternal respiratory distress and hypoxemia. ${ }^{[3]]}$ Some inconsistencies were observed between the first manuscripts in the literature related with COVID-19 infection in pregnant women and abor- 
tion risk. The first study on this topic is a review published in Iran. ${ }^{[39]}$ This manuscript attributed the increase of abortion risk in COVID-19 to another manuscript, ${ }^{[40]}$ but when that manuscript was reviewed, it was seen that SARS virus was reported as the virus increasing abortion risk but it did not mention COVID-19 infection and abortion risk. The second manuscript was published in Am J Obstet Gynecol, but the reference was not cited. ${ }^{[4]}$ Again, although it was reported in another manuscript that the abortion risk increased in coronavirus infections, the increased rates were shown for MERS and SARS infections but not COVID-19. ${ }^{[42]}$ According to the review published on April 17, 2020, COVID-19 infection has not been reported yet in the first trimester. ${ }^{[43]}$ According to another review published in China, 8 of 116 COVID-19 positive pregnant women were detected in the first trimester or early second trimester and abortion was observed in one of these pregnant women $(1 / 8$; $12.5 \%) .{ }^{[34]}$ In another review evaluating the results of 324 pregnant women, pregnancy loss in the first trimester was reported in 4 patients; however, 3 of them are voluntary gestational termination. ${ }^{[35,44]}$ In WAPM study, which is the largest study in the world evaluating 388 pregnant women, 6 cases of first trimester pregnancy loss were reported. ${ }^{[45]}$

The cases which have COVID-19 infection during pregnancy do not have more risk than non-pregnant women, and COVID-19 infection does not cause more severe infections in pregnant-women unlike other respiratory tract infections. ${ }^{[43]}$ According to the review conducted on 147 pregnant patients in China by the World Health Organization in February 16-24, 2020, severe infection risk does not increase in pregnant women by COVID-19 infection unlike influenza. ${ }^{[2]}$

COVID-19 infection may also affect the conception plan of individuals. In an Italian study evaluating 1482 individuals, $37.3 \%$ of individuals with previous conception plan abandoned their conception plan. ${ }^{[46]}$ According to a study published in Turkey, sexual desire and the frequency of sexual intercourse increased in women while desire for pregnancy decreased. ${ }^{[4]}$

Maternal mortality after COVID-19 infection during pregnancy was not reported in the first periods of pandemic, and it was asserted that the morbidity did not increase during pregnancy. ${ }^{[3,48-51]}$ This was considered suspicious as maternal mortality cases were reported with MERS and SARS in the previous Coronavirus pan- demics. However, a total of 17 maternal death cases consisting of 1 case from Iran, ${ }^{[52]} 7$ cases from Iran, ${ }^{[53]} 1$ case from $\operatorname{Iran}^{[54]}$ and again 2 cases from Iran, ${ }^{[5]} 1$ case from England, ${ }^{[56]} 1$ case from the USA, ${ }^{[57]} 1$ case from Sweden ${ }^{[58]}$ and 3 cases in the study of the World Association of Perinatal Medicine which is in publication process ${ }^{[45]}$ were reported afterwards. It is impossible to calculate mortality rate during pregnancy in COVID-19 infection as the reports are currently in the form of case reports. It was also claimed that the increased rate of maternal mortality may not be associated with infection only, it may occur due to the use of uterotonic, antiepileptic and antibiotic drugs less than normal due to the decreased rates of admission to hospital and the low number of clean delivery units as a result, and 12,000 additional maternal mortality cases may be added within 6 months to the annual worldwide mortality rate even in the lowest severe scenario according to the modelling created. ${ }^{[59}$

\section{Covid-19 and Vertical Fetal Transmission}

The most feared impact of maternal infection is the fetal exposure associated with vertical transmission. When any infection is transmitted to fetus from mother, the fetal exposure level may change depending on the variables such as the infection agent type, week of gestation and delivery type. The evidences showing the existence of fetal infection are the typical morphological changes and pathological and laboratory tests shown in baby. Congenital Zika virus infection can be given as an example for morphological exposure. In this infection, microcephaly was found in the newborns and this was shown as the evidence of Zika viral infection. ${ }^{[60]}$ Fetal infection diagnosis can be established specifically by pathological and laboratory tests. However, it is important to conduct these tests properly and on time, and by the nature of the tests, it should be noted that false positive and negative results may be obtained. It is very important to show viral agent pathologically in the fetal organ systems or to produce culture in the samples collected; however, it is not possible in most of the viral agents. Finding COVID-19 viral nucleic acid in adults by using RTPCR is reference standard diagnostic test. Viral agent can also be found by serological tests. In terms of infection diagnosis, it is significant to detect $\operatorname{IgM}$ in cord blood or fetal circulation because maternal IgG may pass through placenta but IgM cannot. The sensitivity and specificity of anti-SARS-CoV-2 IgM are $70.2-88.2 \%$ 
and $96.2-99 \%$, respectively, and therefore further studies are needed for COVID-19 diagnostic performance. ${ }^{[37,61]}$ According to the recommendation of Turkish Neonatal Society, positive respiratory tract or blood test is needed for proven neonatal COVID-19 diagnosis. ${ }^{[6]}$

Although it was claimed that possibility of detecting the virus in placenta is low as the viremia in the symptomatic COVID-19 patients is $1 \%$ and temporary, SARSCoV-2 positivity in the placenta was shown in the following studies. ${ }^{[3]}$ In a study conducted in New York, USA, 32 SARS-CoV-2 positive pregnant women were evaluated, swab samples were collected from the amniotic surface of placenta and from the surfaces between amnion and chorion in 11 of these patients, and SARS$\mathrm{CoV}-2$ positivity was found in 3 of these 11 patients. ${ }^{[63]} \mathrm{In}$ the study evaluating the placentas of 16 COVID-19 positive pregnant women, the authors reported that maternal vascular malperfusion, abnormal or damaged maternal vessels and intervillous thrombus were observed more in these placentas than the control placentas, but acute and chronic inflammation did not increase. ${ }^{[64]}$ Similar placental findings were also reported from the USA ${ }^{[65]}$ In the placental examination performed after the pregnancy was terminated due to preeclampsia and placenta detachment in a 22-week pregnant woman, SARS$\mathrm{CoV}-2$ positivity and intense macrophage accumulation in syncytiotrophoblasts were reported. ${ }^{[6]}$

The study which evaluated 47 pregnancies and 46 neonatal outcomes has been the one of the greatest reviews on fetal transmission so far, and it provides evidences for and against fetal transmission. ${ }^{[37]}$ According to the study evaluating 265 pregnant women who gave birth, vertical transmission risk was quite low. ${ }^{[4]}$ In a case report published in April 2020, it was claimed that fetal vertical transmission is possible. ${ }^{[67]}$ In this report, it was seen that the baby of the pregnant woman, who needed mechanical ventilation on the fifth day of the disease and delivered by the cesarean section, had COVID-19 PCR positivity, tested at 16th hour and confirmed at 48th hour, and intrauterine transmission was considered as the reason. However, amniotic fluid, cord blood and placental infection were not examined in this case. In the case report from China published in the March issue of JAMA, Dong et al. found ground-glass opacities consisted with viral pneumonia in the thorax CT scan performed in the clinic in a 29-year-old and 34-week and 2-day pregnant woman who applied for fever $\left(37.9^{\circ} \mathrm{C}\right)$ and nasal congestion complaints on $28 / 01 / 2020$, and the swab sample collected from the nasopharynx showed SARS-CoV-2 PCR positivity. ${ }^{[68]}$ The pregnant woman was hospitalized and medical treatment was initiated, and consecutive 4 PCR tests also yielded positive results. In the blood antibody test performed on 21/02/2020, the IgG value of the patient was $107.89 \mathrm{AU} / \mathrm{mL}$ and $\mathrm{IgM}$ value was $279.72 \mathrm{AU} / \mathrm{mL}$, and the pregnant woman delivered by the cesarean section by using N-95 mask in negative isolation room on $22 / 02 / 2020$. The baby which was born $3120 \mathrm{~g}$ was quarantined in the newborn intensive care unit without any contact with the mother. In the blood sample taken 2 hours after birth of the baby which showed no symptom, SARS-CoV-2 IgG and IgM levels were found 140.32 AU/mL and 45.83 AU/mL, respectively. It was also found that the cytokine levels (IL-6: $28.26 \mathrm{pg} / \mathrm{mL}$; IL-10: $153.60 \mathrm{pg} / \mathrm{mL}$ ) and leucocyte count $\left(18.08 \times 10^{9} / \mathrm{L}\right)$ of the newborn were elevated. The thorax CT scan was evaluated normal. Swab samples were collected 5 times from the nasopharynx between the postnatal 2nd hour and 16th day, and all SARS-CoV-2 PCR tests yielded negative results. In the SARS-CoV-2 test performed on the newborn on 07/03/2020, IgG level was $69.94 \mathrm{AU} / \mathrm{mL}$ and $\operatorname{IgM}$ level was 11.75 AU/mL, which were still high. The newborn was discharged on 18/03/2020. The RT-PCR test yielded negative result on the breast milk sample collected from the mother on 28/03/2020, mother's SARS-CoV-2 IgG and $\mathrm{IgM}$ levels were found $116.30 \mathrm{AU} / \mathrm{mL}$ and 112.66 $\mathrm{AU} / \mathrm{mL}$, respectively, and medium level resolution was observed in the ground-glass opacities in thorax CT scan. Although RT-PCR was not tested on placenta and amniotic fluid in this case report, the study provides valuable data in terms of showing IgM antibodies in the newborn just two hours after the birth. Considering that IgM antibodies does not exhibit transplacental transmission and IgM antibodies are not produced until 3-7 days after the acute infection, this publication is a significant case report in terms of presenting a case which suggests that a fetus exposed to maternal infection for 23 days during intrauterine period may contract COVID-19 infection through vertical transmission. ${ }^{[68]}$ Some other studies were also published showing vertical transmission after these studies. The summaries of the studies suggesting fetal vertical SARS-CoV-2 transmission are presented in the Table $\mathbf{3}$. 
Table 3. The summaries of the studies asserting fetal vertical SARS-CoV-2 transmission.

\begin{tabular}{|c|c|}
\hline Study & Nen \\
\hline Patane et al. (Italy) $)^{[105]}$ & $\begin{array}{l}\text { In } 22 \text { mothers with positive SARS-CoV-2 PCR result: the nasopharyngeal swabs of } 2 \text { newborns were positive for SARS-CoV-2. } \\
\text { 1st newborn: Vaginal birth, } 37.6 \text { weeks, } 2660 \mathrm{~g}, 9-10 \mathrm{Apgar} \text {, cord pH: } 7.28 \text {, staying in the same room with mother, and being } \\
\text { breastfed. The nasopharyngeal swab right after birth, positive at } 24 \text { th hour and 7th day, the newborn was asymptomatic and } \\
\text { discharged on } 10 \text { th day. Chronic intervillositis of the placenta, there were macrophages and syncytiotrophoblasts were positive } \\
\text { for SARS-CoV-2 RNA. } \\
\text { 2nd newborn: Cesarean section (unreliable NST), } 35.1 \text { weeks, } 2686 \mathrm{~g}, 9-10 \text { Apgar, cord pH: } 7.32 \text {. The newborn was taken to } \\
\text { the follow-up in the newborn intensive care unit. The nasopharyngeal swab right after birth was negative, but positive at 7th } \\
\text { day. The asymptomatic newborn was discharged on } 20 \text { th day. Chronic intervillositis of the placenta, there were macrophages and } \\
\text { syncytiotrophoblasts were positive for SARS-CoV-2 RNA. }\end{array}$ \\
\hline Zeng $\mathrm{H}$ et al. (China) ${ }^{[106]}$ & $\begin{array}{l}6 \text { asymptomatic newborns of } 6 \text { mothers with positive SARS-CoV-2 PCR result were evaluated, all nasopharyngeal } \\
\text { swabs were negative but; } \\
\text { - In } 2 \text { newborns, positive SARS-CoV-2 IgG and IgM, IL-6 elevated } \\
\text { - In } 3 \text { newborns, positive SARS-CoV-2 IgG, negative IgM, IL-6 elevated } \\
\text { - In } 1 \text { newborn, negative SARS-CoV-2 IgG and IgM, IL-6 elevated }\end{array}$ \\
\hline Wang et al. (China) $)^{[107]}$ & $\begin{array}{l}\text { The nasopharyngeal swab of } 1 \text { newborn was positive for SARS-CoV- } 2 \text { in } 1 \text { mother with positive SARS-CoV-2 PCR result. } \\
40 \text { weeks, C/S labor, } 3205 \mathrm{~g}, 8-9 \text { Apgar, follow-up in the newborn intensive care. Lymphopenia, impaired LFT, and elevated } \\
\text { creatinine kinase were detected in the newborn. Nasopharyngeal swab at 36th hour is SARS-CoV- } 2 \text { positive. Cord } \\
\text { blood, placenta and breast milk were negative for SARS-CoV-2. The nasopharyngeal and anal swabs at 16th day } \\
\text { are negative, discharged at } 17 \text { th day. }\end{array}$ \\
\hline Zeng L et al. (China) $)^{[108]}$ & $\begin{array}{l}\text { Nasopharyngeal swabs of } 3 \text { newborns were positive for SARS-CoV-2 in } 33 \text { mothers with positive SARS-CoV-2 PCR result. } \\
\text { 1st newborn: } 40 \text { weeks, CS birth (amniotic fluid with meconium and COVID-19 pneumonia in mother). Lethargy and fever } \\
\text { in the newborn on postnatal 2nd day and the pneumonia in the chest radiography. The laboratory tests were normal. } \\
\text { The nasopharyngeal and anal swabs were positive on the } 2 \text { nd and } 4 \text { th days, and negative on the } 6 \text { th day. } \\
\text { 2nd newborn: } 40.4 \text { weeks, CS birth (COVID-19 pneumonia in the mother). Lethargy, vomiting and fever in the newborn after } \\
\text { birth and the pneumonia in the chest radiography. Leukocytosis, lymphocytopenia and elevated creatine kinase in the laboratory } \\
\text { tests. The nasopharyngeal and anal swabs were positive on the } 2 \text { nd and } 4 \text { th days, and negative on the } 6 \text { th day. } \\
\text { 3rd newborn: } 31.2 \text { weeks, CS birth (fetal distress and COVID-19 pneumonia in the mother). Resuscitation needed, and Apgar scores } \\
\text { were 3,4 and 5. Postnatal RDS and pneumonia. Additionally, sepsis, leukocytosis, thrombocytopenia and coagulopathy. The } \\
\text { nasopharyngeal and anal swabs were positive on the } 2 \text { nd and 4th days, and negative on the 7th day. }\end{array}$ \\
\hline Alzamora et al. (Peru) ${ }^{[6]]}$ & $\begin{array}{l}\text { The nasopharyngeal swab of } 1 \text { newborn was positive for SARS-CoV-2 in } 1 \text { mother who was positive for SARS-CoV-2 PCR. } \\
33 \text { weeks, CS birth, } 2970 \mathrm{~g}, 6-8 \text { Apgar, the newborn was intubated as mother's sedation level was high. Separated from the } \\
\text { mother, followed up in the newborn intensive care unit and not provided breast milk. IgG and IgM values of the newborn were } \\
\text { negative. The nasopharyngeal swab was negative at } 16 \text { th and 48th hours. On 6th day, the newborn had mild dyspnea and } \\
\text { needed oxygen. }\end{array}$ \\
\hline Dong et al. (China) $)^{[68]}$ & $\begin{array}{l}1 \text { newborn of } 1 \text { mother with positive SARS-CoV-2 PCR result was evaluated. } \\
37.6 \text { weeks, CS birth, } 3120 \mathrm{~g}, 9-10 \text { Apgar. Separated from the mother, followed up in the newborn intensive care unit. SARS-CoV-2 } \\
\text { lgG and IgM were positive at } 2 \text { nd hour. IL-6 elevated and leukocytosis was present. } 5 \text { nasopharyngeal swabs from } 2 \text { nd hour } \\
\text { to } 16 \text { th day were negative. The newborn was discharged on } 25 \text { th day. The breast milk was PCR negative. }\end{array}$ \\
\hline Ferrazzi et al. (Italy) $)^{[104]}$ & $\begin{array}{l}\text { The nasopharyngeal swabs of } 3 \text { newborns were positive for SARS-CoV- } 2 \text { in } 42 \text { mothers with positive SARS-CoV-2 PCR result. } \\
2 \text { postpartum mothers were diagnosed with COVID-19, and they breastfed their babies during this period without waring mask, } \\
\text { and the newborns were found to be positive for SARS-CoV-2. Third newborn was separated due to postpartum bleeding, and } \\
\text { the mother was diagnosed with COVID-19 in the following days, and the test result of the newborn was also positive. }\end{array}$ \\
\hline Yu et al. (China) ${ }^{[109]}$ & $\begin{array}{l}\text { The nasopharyngeal swab of } 1 \text { newborn was positive for SARS-CoV-2 in } 7 \text { mothers with positive SARS-CoV-2 PCR result. } \\
\text { The newborn was found to be positive for SARS-CoV- } 2 \text { at postnatal } 36 \text { th hour. Following } 2 \text { tests of the newborn whose mild } \\
\text { respiratory distress improved were negative, and the newborn was discharged in } 2 \text { weeks. It was reported that the intrauterine } \\
\text { transmission may not be the case in this pregnancy as placenta and cord blood were negative for SARS-CoV- } 2 \text {. }\end{array}$ \\
\hline Yang et al. (China) $)^{[110]}$ & $\begin{array}{l}\text { The nasopharyngeal swab of } 1 \text { newborn was negative for SARS-CoV-2 but IgG and IgM were positive in } 7 \text { mothers } \\
\text { with positive SARS-CoV- } 2 \text { PCR result. } \\
\text { In the rapid test of the baby born by cesarean section due to PRM at } 30.6 \text { weeks of gestation, SARS-CoV-2 IgG and IgM were } \\
\text { found positive, } 2 \text { PCR tests resulted negative. The newborn was discharged at } 29 \text { th day. }\end{array}$ \\
\hline Zamaniyan et al. (Iran) $)^{[54]}$ & $\begin{array}{l}\text { The nasopharyngeal swab of } 1 \text { newborn was negative for SARS-CoV-2 but IgG and IgM were positive in } 1 \text { mother } \\
\text { with positive SARS-CoV- } 2 \text { PCR result. } \\
32 \text { weeks, SARS-CoV- } 2 \text { pneumonia in mother, sample was collected from the amniotic fluid during labor by CS. The newborn } \\
\text { was } 2350 \text { g } 8 \text { - } 9 \text { Apgar. The first nasal and throat swabs of the newborn were negative, but amniotic fluid was positive for } \\
\text { SARS-CoV-2. The newborn swab at } 24 \text { th hour was positive. The mother died, but the newborn is in good health. }\end{array}$ \\
\hline WAPM study ${ }^{[45]}$ & $\begin{array}{l}\text { The nasopharyngeal swab of } 1 \text { newborn was positive for SARS-CoV- } 2 \text {. } \\
\text { In the asymptomatic newborn with positive nasopharyngeal swab right after the birth, PCR was negative on 14th day. } \\
\text { Amniotic and placental samples were not tested }\end{array}$ \\
\hline Carosso et al. ${ }^{[111]}$ (Italy) & $\begin{array}{l}\text { The nasopharyngeal swab of } 1 \text { newborn was positive for SARS-CoV-2. } \\
37 \text { weeks, vaginal birth, } 3120 \mathrm{~g}, 9-10 \text { Apgar, the nasopharyngeal swab of the asymptomatic newborn was positive. The } \\
\text { nasopharyngeal swab at } 37 \text { th hour was negative, placental swab was negative, SARS-CoV-2 IgG was positive and lgM was } \\
\text { negative in the cord blood. }\end{array}$ \\
\hline
\end{tabular}




\section{COVID-19 and Breastfeeding Period}

Breastfeeding after delivery in patients who have COVID-19 infection is discussed by neonatology societies, and the policies vary in each country. According to the recommendation of Public Health General Directorate of the Turkish Ministry of Health, breastfeeding can be done by taking measures after advising mother and providing necessary information. Accordingly, if mother decides to breastfeed her baby, it can be done by wearing medical/surgical mask after ensuring hand hygiene. If mother wants to extract breast milk, it can be done by ensuring hand hygiene, cleaning nipple and wearing medical/surgical mask.

\section{Management of COVID-19 Infection in Pregnant Women}

As asymptomatic virus spread is possible, it is recommended to do COVID-19 test to all pregnant women who apply to some centers for labor; however, most of the centers cannot do these tests. According to a study conducted in New York, USA, 33 (15.4\%) of 215 pregnant women who applied to hospital for labor between March 22 and April 4 were found SARS-CoV-2 positive, and $29(88 \%)$ of these 33 patients were asymptomatic. ${ }^{[13]}$ A similar study was conducted in England and it was found that $8(88.9 \%)$ of 9 patients with positive results were asymptomatic. ${ }^{[14]}$ In another study carried out in the USA, each pregnant woman applied to hospital underwent SARS-CoV-2 test, and it was shown that $43.5 \%$ of the positive cases were asymptomatic. ${ }^{[15]}$ Therefore, the perception that the pregnant women without symptom do not have the disease should be changed, and personal protection and hygiene rules should be followed assuming that each visiting individual is a potential patient.

During the pandemic, it was made compulsory to wear mask for healthcare professionals in most of the hospitals who are in contact with patients. Healthcare professionals, who contact with pregnant women that are diagnosed with COVID-19 infection or suspected to have infection due to contact, should use personal protective equipment. ${ }^{[69]}$ Visiting policies should be reviewed in order to decrease the infection risk of patients and visitors. The patients applied for labor should stay in the same room as much as possible, and it should be avoided to change rooms.

Various societies have different algorithms in the presence of suspected COVID-19 infection in a pregnant patient. As the patient number increases, algorithms also become diversified. The algorithm of the American College of Obstetricians and Gynecologists (ACOG) has been updated on May 19, 2020. ${ }^{[70]}$ The algorithms of the International Federation of Gynecology and Obstetrics (FIGO) on COVID-19 during pregnancy and at labor were prepared by Poon et al. ${ }^{[71]}$ The consensus report containing the experience of China in which the infection appeared first has a pregnancy follow-up algorithm. ${ }^{[72]}$ There is an opinion manuscript about "New Coronavirus Infection 2019" during pregnancy, labor and postpartum period published by Turkish Perinatology Society. ${ }^{[73]}$

Under today's conditions, the best precaution method is to protect ourselves as there is no primary treatment and vaccination for COVID-19 infection. Social isolation should certainly be practiced in regions with intense infection. It is recommended to keep at least $1.5 \mathrm{~m}$ distance among individuals in crowded areas where contact potential increases. It was shown that social isolation decreases the rate of pandemic. ${ }^{[43]}$ Hygiene rules should be followed, hands should be washed by soap for at least 20 seconds after contacting with objects such as computers, mobile phones, door handles etc. which are used commonly, and face, eyes, mouth and nose should not be touched by hands after any contact. Cleaning shared areas is also important. Pregnant women should be careful in the waiting rooms of healthcare centers. Pregnant women with high risk, who are diagnosed with COVID19 infection and whose examinations still continue, should be isolated and these patients should stay away from general pregnant women population. It is important to establish centers that only the pregnant women in the same categories can apply in order to enable these pregnant women to apply under emergency conditions.

It is unknown how much routine follow-up frequencies of pregnant women will change or have to change due to COVID-19 infection. In order to decrease the contagion risk, the follow-up frequency in physical examination form at hospitals can be decreased in pregnant women with low risk in particular, and the remaining follow-ups can be maintained as tele-healthcare services via phone/Internet. ${ }^{[4]}$ Although it is not certainly known which patients have less risk, Dotters et al. reported that risky pregnancies are under lower risk in cases such as hypothyroidism, smoking, absence of medical complication, previous cesarean section, advanced maternal age ( $<40$ years), IVF pregnancies, obesity class 
1 (body mass index: 30-35) and class 2 (body mass index: 35-40), and mild anxiety/depression. ${ }^{[43]}$ Dichorionicdiamniotic and monochorionic-diamniotic pregnancies, and pregnancies with marginal and velamentous cord insertion, class 3 obesity and placenta previa were categorized as low risk pregnancies, but extra ultrasound examination was recommended for these patients. ${ }^{[43]}$

If a pregnant patient is suspected for COVID-19 infection, chest radiography or lung CT scan should be performed by protecting the abdominal region after the consent of patient is obtained, and the examination should not be avoided due to fetal concerns. ${ }^{[70]}$ When a pregnant woman is exposed to high dose of radiation, growth retardation, microcephaly and mental deficiency may be seen but the high dose was described as $>610$ $\mathrm{mGy}{ }^{[7,75]}$ The radiation dose is $0.0005-0.01 \mathrm{mGy}$ in a single dose chest radiography and $0.01-0.66 \mathrm{mGy}$ in a single lung CT scan or pulmonary angiography, and these levels are very low compared to the hazardous dose mentioned above. ${ }^{[76-78]}$ Lung CT scan is quite sensitive in the diagnosis of COVID-19 and it was asserted that it can be used primarily for the diagnosis of COVID-19 in epidemic regions (79). When PCR test is considered as a gold standard, the sensitivity, specificity, positive predictive value and negative predictive value of lung CT scan for COVID-19 diagnosis are $97 \%, 25 \%, 65 \%$ and $83 \%$, respectively. ${ }^{[79]}$ The radiological findings in pregnant women with COVID-19 positivity are similar to the findings of non-pregnant patients.$^{[4]}$

Maternal lung ultrasound scan can be used for the diagnosis of COVID-19 infection. Thickened pleural line and "white lung" exhibiting distribution in patched form together with generalized hyperechoic vertical artifacts in the lung ultrasound scan are the typical ultrasound findings. ${ }^{[80]}$

Pregnant women with mild COVID-19 infection without any coexisting morbidity can be followed at home by resting, hydration and symptomatic treatments. Gestational follow-ups of these pregnant women can be done by phone. ${ }^{[70]}$ Fetal growth should be followed up closely in pregnant women who recover from COVID19 infection but not give birth yet, because it is known that fetal growth is slowed down in other respiratory viruses causing severe infection. ${ }^{[81]}$ The use of nonsteroidal anti-inflammatory drugs during COVID-19 infection is controversial. However, as there is no data confirming it, ACOG recommends pregnant women with preeclampsia risk using aspirin. ${ }^{[82]}$ On the other hand, it was also recommended discontinuing aspirin and not taking again until full recovery if a patient using prophylactic aspirin is diagnosed with SARS-CoV-2 as aspirin may cause severe bleeding in pregnant women who particularly contract COVID-19 infection at the 3 rd trimester and are thrombocytopenic. ${ }^{[83,84]}$ If there is no medical indication in COVID-19 positive pregnant women who undergo ambulatory follow-up and are on 3rd trimester, 14-day quarantine should be waited to end before labor induction or planned cesarean section or negative test result should be waited. ${ }^{[81]}$

If week of gestation is below 34 weeks in a pregnant woman who applies for preterm labor and has COVID19 infection, corticosteroid use should be customized for lung maturation. If it is above 34 weeks, corticosteroids should not be used even though preterm labor risk is high, because it was asserted that steroids may exacerbate the prognosis in non-gestational COVID-19 infections. ${ }^{[85]}$ Acute progressive coagulopathy may develop in pregnant women contracting COVID-19 infection during third trimester. Therefore, the predisposition towards bleeding during prenatal and postnatal periods should be taken into consideration in the patients. ${ }^{[86]}$

\section{Treatment in Pregnant Women with Suspected/Potential COVID-19 Infection}

The pregnant women with suspected, potential or confirmed COVID-19 infection should be followed up ideally in tertiary centers which are capable of providing isolation and taking protective measures. The pregnant women with suspected or potential COVID-19 infection should be isolated, and the pregnant women with confirmed COVID-19 infection should be followed up in negative-pressure rooms. ${ }^{[7]}$ In its management, fluid and electrolyte balance is paid attention and symptomatic treatment is administered by antipyretic and antidiarrheic agents. Ibuprofen can be used when necessary. ${ }^{[87]}$ Vital findings and oxygen saturation level should be monitored closely to keep maternal hypoxia at minimum level, arterial blood gas should be checked, lung imaging should be repeated when necessary, and full blood count, kidney and liver function tests and bleeding parameters should be measured regularly. Cardiotocography should be used for fetal heart beats after 23-28 weeks of gestation and gestational follow-up should be done according to clinical condition. The appointments should be delayed during isolation or until positive result or 2 negative results are obtained. 


\section{Treatment in Pregnant Women with Confirmed COVID-19 Infection}

Mild disease: Fluid and electrolyte balance is paid attention, and symptomatic treatment is administered by antipyretic and antidiarrheic agents. Although there are drawbacks about the use of ibuprofen, WHO does not state that it should not be used. ${ }^{[87]}$

There is no special antiviral treatment for COVID19 infection. The antiretroviral drugs are used in the patients with severe symptoms. Currently, remdesivir and chloroquine are the strongest candidates for the use in this infection. While the use of remdesivir, of which in vitro effect was shown for COVID-19, seems safe in pregnant women, its Phase 3 studies have been conducted. ${ }^{[88]} \mathrm{A}$ case on remdesivir use during pregnancy and the use of plasma obtained from a recovered patient was also reported. ${ }^{[89]}$ Chloroquine phosphate which is an antimalarial drug has antiviral and immunomodulator effects, and it causes COVID-19 to regress clinically, radiologically and serologically. ${ }^{[00]}$ There are evidences showing that lopinavir-ritonavir (LPV/r) may help in the treatment of COVID-19. ${ }^{[1]}$ Although there is no evidence for its safety in pregnant women with COVID-19, it was shown in the studies conducted on the pregnant women with HIV that it did not increase the risks for fetal anomaly, preterm labor and low birth weight. ${ }^{[92]}$ Ribavirin and baricitinib should not be used as they are fetotoxic. For now, the directives of the healthcare institutions of the countries should be followed for drug use, and the consents of patients should be obtained for the drugs to be used in pregnant women. Bacterial infections should be monitored by blood and urine culture tests, necessary treatments should be provided in case of any secondary bacterial infection. Cardiotocography should be used for fetal heart beats after 23-28 weeks of gestation and gestational follow-up should be done according to clinical condition.

Severe and critical disease: While high SOFA (sequential organ failure assessment) score and $>1$ $\mathrm{mg} / \mathrm{mL} \mathrm{D}$-dimer level is associated with increased COVID-19 mortality in non-pregnant patients, its use is difficult in pregnant patients. ${ }^{[33]}$ As D-dimer level increases during pregnancy, its use is limited. The use of SOFA score is more appropriate by adjusting creatinine level for pregnant patients. According to the study evaluating 46 pregnant women with positive SARS-CoV-2 result, severe disease developed in $15 \%$ of the patients, and it was reported that these patients were overweight or
Table 4. The changes in the arterial blood gas measurements in pregnancy. ${ }^{[112]}$

\begin{tabular}{lccc}
$\begin{array}{l}\text { Arterial blood } \\
\text { gas measurement }\end{array}$ & $\begin{array}{c}\text { 1st } \\
\text { trimester }\end{array}$ & $\begin{array}{c}\text { 3rd } \\
\text { trimester }\end{array}$ & $\begin{array}{c}\text { Non- } \\
\text { pregnant } \\
\text { patient }\end{array}$ \\
\hline $\mathrm{pH}$ & $7.42-7.46$ & 7.43 & 7.4 \\
$\mathrm{PaO}_{2}(\mathrm{mmHg})$ & $105-106$ & $101-106$ & 93 \\
$\mathrm{PaCO}_{2}(\mathrm{mmHg})$ & $28-29$ & $26-20$ & 37 \\
Serum $\mathrm{HCO}_{3}(\mathrm{mEq} / \mathrm{L})$ & 18 & 17 & 23 \\
\hline
\end{tabular}

obese with underlying diseases and therefore it should be paid attention in this group of patients. ${ }^{[69]}$

The severity of COVID-19 pneumonia should be graded according to the guidelines of American Thoracic Society. ${ }^{[94]}$ Morbidity and mortality rates increase in pregnant women with severe COVID-19 pneumonia, and therefore an aggressive treatment is required. The mortality of a pregnant woman due to COVID-19 was first reported in Iran. ${ }^{[52]}$ These patients should be monitored preferably in a negative-pressure room in intensive care and by lying on their left sides, they should be supported with oxygen and hydration, and followed up by a multidisciplinary team. Any secondary bacterial infection should be treated accordingly, and their blood pressure and fluid balance should be monitored closely.

When evaluating pregnant women for COVID-19 infection, it should be kept in mind that their vital findings and acid/base parameters are different than nonpregnant patients (Table 4). The oxygen saturation should be kept at $95 \%$ and above in pregnant patients with positive COVID-19 result. Ventilation type should be decided by intensive care specialists. The use of lowmolecular-weight heparin ( $\mathrm{LMWH})$ is on the agenda as macroscopic bleeding areas and microthromboses can be observed in the lungs. Cardiotocography should be used for fetal heart beats after 23-28 weeks of gestation and gestational follow-up should be done according to clinical condition. The need for preterm labor with medical indication should be decided by a multidisciplinary team led by Perinatology department by evaluating the condition of patient.

Even though the infection is severe, it is not a labor induction. ${ }^{[81]}$ If pregnant woman is at term, there is no cesarean indication except obstetric indications. ${ }^{[82]}$ In the assessment of 13 patients who had COVID-19 infection, vaginal secretion samples showed negative results. ${ }^{[95]}$ In rare cases where patients are at critical condition, labor 
may be needed to improve respiratory functions. When emergency cesarean section was performed in a patient with severe hypoxemia, hemodynamic collapse and COVID-19 positive twin pregnancy, it was reported that hemodynamic condition and respiratory function were improved quicklyy. ${ }^{[96]}$ It was reported in England that 2 preterm patients' condition improved quickly by emergency cesarean section, and that it was highlighted that this is different than pregnant women with influenza. ${ }^{[97]}$ In infection with mild or medium severity, it is not necessary to make 2nd stage of labor passive except obstetric indications, but operative labor can be performed in an intubated patient. The opinion of Turkish Neonatal Society regarding the perinatal and labor periods of a patient with COVID-19 infection can be accessed via its website. $^{[2]}$

The World Association of Perinatal Medicine (WAPM) initiated a multi-centered joint database globally to present the problems related with COVID-19 pandemic and pregnancy, and to help pregnant women and their families. It is expected that the first of this joint database will be completed by May 1, the second part by August 1, and the third part by November 1, 2020. Those who would like to participate in this initiative may visit http://www.worldperinatal.org/covid-19/.

\section{Conclusion}

In our review, we aimed to present the relationship between pregnancy and COVID-19 under the light of the up-to-date data. The data in this review will be updated as new data are reported. The last update is on June 8, 2020.

Conflicts of Interest: No conflicts declared.

\section{References}

1. Li Q, Guan X, Wu P, Wang X, Zhou L, Tong Y, et al. Early transmission dynamics in Wuhan, China, of novel coronavirus-infected pneumonia. N Engl J Med 2020;382:1199207. [PubMed] [CrossRef]

2. WHO. Report of the WHO-China Joint Mission on Coronavirus Disease 2019 (COVID-19). [Internet]. Geneva: World Health Organization. [cited 2020 Feb 16-24] Available from: https:/www.who.int/docs/default-source/coronaviruse/ who-china-joint-mission-on-covid-19-final-report.pdf

3. WHO. MERS global summary and assessment of risk 2019. [Internet]. Geneva: World Health Organization. [cited 2019 Jul 16-24] Available from: https://apps.who.int/iris/bitstream/ handle/10665/326126/WHO-MERS-RA-19.1-eng.pdf?ua=1
4. WHO. WHO guidelines for the global surveillance of severe acute respiratory syndrome (SARS). Updated recommendations, October 2004 [Internet]. Geneva: World Health Organization. [cited 2004 Oct] Available from: https://www. who.int/csr/resources/publications/WHO_CDS_CSR_ARO_ 2004_1.pdf?ua=1

5. WHO. Consensus document on the epidemiology of severe acute respiratory syndrome (SARS). Global Meeting on the Epidemiology of SARS; 2003. [Internet]. Geneva: World Health Organization. [cited 2003 May 16-17] Available from: https://apps.who.int/iris/handle/10665/70863

6. CDC. Disease burden of influenza. [Internet] Atlanta, GA: Centers for Disease Control and Prevention, National Center for Immunization and Respiratory Diseases (NCIRD). [updated 2020 Apr 17] Available from: https://www.cdc.gov/flu/ about/burden/index.html

7. Coronavirus disease 2019 (COVID-19): situation report. [Internet]. Geneva: World Health Organization. [cited 2020 Mar 6] Available from: https://www.who.int/docs/defaultsource/coronaviruse/situation-reports/20200306-sitrep-46covid-19.pdf?sfvrsn=96b04adf_4

8. Fraser C, Donnelly CA, Cauchemez S, Hanage WP, Van Kerkhove MD, Hollingsworth TD, et al.; WHO Rapid Pandemic Assessment Collaboration. Pandemic potential of a strain of influenza A (H1N1): early findings. Science 2009; 324(5934):1557-61. [PubMed] [CrossRef]

9. Epidemiology Working Group for NCIP Epidemic Response, Chinese Center for Disease Control and Prevention. The epidemiological characteristics of an outbreak of 2019 novel coronavirus diseases (COVID-19) in China. [Article in Chinese]. Zhonghua Liu Xing Bing Xue Za Zhi 2020;41:145-51. [PubMed] [CrossRef]

10. Huang C, Wang Y, Li X, Ren L, Zhao J, Hu Y, et al. Clinical features of patients infected with 2019 novel coronavirus in Wuhan, China. Lancet 2020;395(10223):497-506. [PubMed] [CrossRef]

11. Qian X, Ren R, Wang Y, Guo Y, Fang J, Wu ZD, et al.; Members of Steering Committee, Society of Global Health, Chinese Preventive Medicine Association. Fighting against the common enemy of COVID-19: a practice of building a community with a shared future for mankind. Infect Dis Poverty 2020;9:34. [PubMed] [CrossRef]

12. Yang R, Gui X, Xiong Y. Comparison of clinical characteristics of patients with asymptomatic vs symptomatic Coronavirus Disease 2019 in Wuhan, China. JAMA Netw Open 2020;3: e2010182. [PubMed] [CrossRef]

13. Sutton D, Fuchs K, D’Alton M, Goffman D. Universal screening for SARS-CoV-2 in women admitted for delivery. N Engl J Med 2020;382:2163-4. [PubMed] [CrossRef]

14. Khalil A, Hill R, Ladhani S, Pattisson K, O’Brien P. Severe acute respiratory syndrome Coronavirus 2 in pregnancy: symptomatic pregnant women are only the tip of the iceberg. Am J Obstet Gynecol 2020;S0002-9378(20)30529-9. [PubMed] [CrossRef] 
15. Miller ES, Grobman WA, Sakowicz A, Rosati J, Peaceman AM. Clinical implications of universal severe acute respiratory syndrome Coronavirus 2 (SARS-CoV-2) testing in pregnancy. Obstet Gynecol 2020. doi:10.1097/AOG.0000000000003983 [PubMed] [CrossRef]

16. Stumpfe FM, Titzmann A, Schneider MO, Stelzl P, Kehl S, Fasching PA, et al. SARS-CoV-2 infection in pregnancy - a review of the current literature and possible impact on maternal and neonatal outcome. Geburtshilfe Frauenheilkd 2020; 80:380-90. [PubMed] [CrossRef]

17. Madinger NE, Greenspoon JS, Ellrodt AG. Pneumonia during pregnancy: has modern technology improved maternal and fetal outcome? Am J Obstet Gynecol 1989;161:657-62. [PubMed] [CrossRef]

18. Rigby FB, Pastorek JG 2nd. Pneumonia during pregnancy. Clin Obstet Gynecol 1996;39:107-19. [PubMed] [CrossRef]

19. Benedetti TJ, Valle R, Ledger WJ. Antepartum pneumonia in pregnancy. Am J Obstet Gynecol 1982;144:413-7. [PubMed] [CrossRef]

20. Berkowitz K, LaSala A. Risk factors associated with the increasing prevalence of pneumonia during pregnancy. Am J Obstet Gynecol 1990;163:981-5. [PubMed] [CrossRef]

21. Wong SF, Chow KM, Leung TN, Ng WF, Ng TK, Shek CC, et al. Pregnancy and perinatal outcomes of women with severe acute respiratory syndrome. Am J Obstet Gynecol 2004;191: 292-7. [PubMed] [CrossRef]

22. Alfaraj SH, Al-Tawfiq JA, Memish ZA. Middle East Respiratory Syndrome Coronavirus (MERS-CoV) infection during pregnancy: report of two cases \& review of the literature. J Microbiol Immunol Infect 2019;52:501-3. [PubMed] [CrossRef]

23. Schwartz DA, Graham AL. Potential maternal and infant outcomes from (Wuhan) Coronavirus 2019-nCoV infecting pregnant women: lessons from SARS, MERS, and other human coronavirus infections. Viruses 2020;12:194. [PubMed] [CrossRef]

24. Harris JW. Influenza occurring in pregnant women: a statistical study of thirteen hundred and fifty cases. JAMA 1919;72: 978-80. [CrossRef]

25. Freeman DW, Barno A. Deaths from Asian influenza associated with pregnancy. Am J Obstet Gynecol 1959;78:1172-5. [PubMed] [CrossRef]

26. Callaghan WM, Creanga AA, Jamieson DJ. Pregnancy-related mortality resulting from influenza in the United States during the 2009-2010 pandemic. Obstet Gynecol 2015;126:48690. [PubMed] [CrossRef]

27. Cox S, Posner SF, McPheeters M, Jamieson DJ, Kourtis AP, Meikle S. Hospitalizations with respiratory illness among pregnant women during influenza season. Obstet Gynecol 2006; 107:1315-22. [PubMed] [CrossRef]

28. Ergonul O, Alan S, Ak O, Sargin F, Kanturk A, Gunduz A, et al.; Turkish Society of Clinical Microbiology and Infectious Diseases (KLIMIK); Pandemic Influenza Study Group. Predictors of fatality in pandemic influenza A (H1N1) virus infection among adults. BMC Infect Dis 2014;14:317. [PubMed] [CrossRef]
29. Neuzil KM, Reed GW, Mitchel EF, Simonsen L, Griffin MR. Impact of influenza on acute cardiopulmonary hospitalizations in pregnant women. Am J Epidemiol 1998;148:1094102. [PubMed] [CrossRef]

30. Chen H, Guo J, Wang C, Luo F, Yu X, Zhang W, et al. Clinical characteristics and intrauterine vertical transmission potential of COVID-19 infection in nine pregnant women: a retrospective review of medical records. Lancet 2020;395(10226):809-15. [PubMed] [CrossRef]

31. Zhu H, Wang L, Fang C, Peng S, Zhang L, Chang G, et al. Clinical analysis of 10 neonates born to mothers with 2019nCoV pneumonia. Transl Pediatr 2020;9:51-60. [PubMed] [CrossRef]

32. Della Gatta AN, Rizzo R, Pilu G, Simonazzi G. Coronavirus disease 2019 during pregnancy: a systematic review of reported cases. Am J Obstet Gynecol 2020; S0002-9378(20)30438-5. [PubMed] [CrossRef]

33. Zaigham M, Andersson O. Maternal and perinatal outcomes with COVID-19: a systematic review of 108 pregnancies. Acta Obstet Gynecol Scand 2020;99:823-9. [PubMed] [CrossRef]

34. Yan J, Guo J, Fan C, Juan J, Yu X, Li J, et al. Coronavirus disease 2019 (COVID-19) in pregnant women: a report based on 116 cases. Am J Obstet Gynecol 2020;S0002-9378(20)304622. [PubMed] [CrossRef]

35. Juan J, Gil MM, Rong Z, Zhang Y, Yang H, Poon LC. Effects of coronavirus disease 2019 (COVID-19) on maternal, perinatal and neonatal outcomes: a systematic review. Ultrasound Obstet Gynecol 2020. doi:10.1002/uog.22088 [PubMed] [CrossRef]

36. Public Health Agency of Sweden's brief report: pregnant and postpartum women with severe acute respiratory syndrome Coronavirus 2 infection in intensive care in Sweden. Acta Obstet Gynecol Scand 2020;99:819-2. [PubMed] [CrossRef]

37. Lamouroux A, Attie-Bitach T, Martinovic J, Leurez-Ville M, Ville Y. Evidence for and against vertical transmission for SARS-CoV-2 (COVID-19). Am J Obstet Gynecol 2020;S00029378(20)30524-X. [PubMed] [CrossRef]

38. Yang Z, Liu Y. Vertical transmission of Severe Acute Respiratory Syndrome Coronavirus 2: a systematic review. Am J Perinatol 2020. doi:10.1055/s-0040-1712161 [PubMed] [CrossRef]

39. Panahi L, Amiri M, Pouy S. Risks of novel Coronavirus disease (COVID-19) in pregnancy; a narrative review. Arch Acad Emerg Med 2020;8:e34. [PubMed] [CrossRef]

40. Favre G, Pomar L, Musso D, Baud D. 2019-nCoV epidemic: what about pregnancies? Lancet 2020;395(10224):e40. [PubMed] [CrossRef]

41. Dashraath P, Wong JLJ, Lim MXK, Lim LM, Li S, Biswas A, et al. Coronavirus disease 2019 (COVID-19) pandemic and pregnancy. Am J Obstet Gynecol 2020;222:521-31. [PubMed] [CrossRef]

42. Di Mascio D, Khalil A, Saccone G, Rizzo G, Buca D, Liberati $M$, et al. Outcome of Coronavirus spectrum infections (SARS, MERS, COVID 1-19) during pregnancy: a systematic review 
and meta-analysis. Am J Obstet Gynecol MFM 2020;2(Suppl 2):100107. [PubMed] [CrossRef]

43. Dotters-Katz SK, Hughes BL. Considerations for obstetric care during the COVID-19 pandemic. Am J Perinatol 2020; 37:773-9. [PubMed] [CrossRef]

44. Wu X, Sun R, Chen J, Xie Y, Zhang S, Wang X. Radiological findings and clinical characteristics of pregnant women with COVID-19 pneumonia. Int J Gynaecol Obstet 2020;150:5863. [PubMed] [CrossRef]

45 Saccone G, Sen C, Di Mascio D, Galindo A, Grünebaum A, Yoshimatsu J, et al. WAPM (World Association of Perinatal Medicine) working group on COVID-19. Maternal and perinatal outcomes of pregnant women with Coronavirus Disease 2019 (COVID-19): The WAPM study on COVID-19. 2020, Lancet, under review.

46. Micelli E, Cito G, Cocci A, Polloni G, Russo GI, Minervini A, et al. Desire for parenthood at the time of COVID-19 pandemic: an insight into the Italian situation. J Psychosom Obstet Gynaecol 2020. doi:10.1080/0167482X.2020.1759545 [PubMed] [CrossRef]

47. Yuksel B, Ozgor F. Effect of the COVID-19 pandemic on female sexual behavior. Int J Gynaecol Obstet 2020;150:98102. [PubMed] [CrossRef]

48. Chen L, Li Q, Zheng D, Jiang H, Wei Y, Zou L, et al. Clinical characteristics of pregnant women with Covid-19 in Wuhan, China. N Engl J Med 2020;382:e100. [PubMed] [CrossRef]

49. Qiancheng X, Jian S, Lingling P, Lei H, Xiaogan J, Weihua L, et al. Coronavirus disease 2019 in pregnancy. Int J Infect Dis 2020;95:376-83. [PubMed] [CrossRef]

50. Ferrazzi EM, Frigerio L, Cetin I, Vergani P, Spinillo A, Prefumo F, et al. COVID-19 Obstetrics Task Force, Lombardy, Italy: executive management summary and short report of outcome. Int J Gynaecol Obstet 2020;149:377-8. [PubMed] [CrossRef]

51. Breslin N, Baptiste C, Gyamfi-Bannerman C, Miller R, Martinez R, Bernstein K, et al. COVID-19 infection among asymptomatic and symptomatic pregnant women: two weeks of confirmed presentations to an affiliated pair of New York City hospitals. Am J Obstet Gynecol MFM 2020;2:100118. [PubMed] [CrossRef]

52. Karami P, Naghavi M, Feyzi A, Aghamohammadi M, Novin MS, Mobaien A, et al. Mortality of a pregnant patient diagnosed with COVID-19: a case report with clinical, radiological, and histopathological findings. Travel Med Infect Dis 2020;101665. [Withdrawn at June 2020] [PubMed] [CrossRef]

53. Hantoushzadeh S, Shamshirsaz AA, Aleyasin A, Seferovic MD, Aski SK, Arian SE, et al. Maternal death due to COVID19 disease. Am J Obstet Gynecol 2020;S0002-9378(20)305160. [PubMed] [CrossRef]

54. Zamaniyan M, Ebadi A, Aghajanpoor Mir S, Rahmani Z, Haghshenas M, Azizi S. Preterm delivery in pregnant woman with critical COVID-19 pneumonia and vertical transmission. Prenat Diagn 2020;10.1002/pd.5713. [PubMed] [CrossRef]
55. Karimi-Zarchi M, Neamatzadeh H, Dastgheib SA, Abbasi H, Mirjalili SR, Behforouz A, et al. Vertical transmission of Coronavirus Disease 19 (COVID-19) from infected pregnant mothers to neonates: a review. Fetal Pediatr Pathol 2020;39: 246-50. [PubMed] [CrossRef]

56. Ahmed I, Azhar A, Eltaweel N, Tan BK. First Covid-19 maternal mortality in the UK associated with thrombotic complications. Br J Haematol 2020;10.1111/bjh.16849. [PubMed] [CrossRef]

57. Vallejo V, Ilagan JG. A postpartum death due to Coronavirus Disease 2019 (COVID-19) in the United States. Obstet Gynecol 2020. doi:10.1097/AOG.0000000000003950 [PubMed] [CrossRef]

58. Westgren M, Pettersson K, Hagberg H, Acharya G. Severe maternal morbidity and mortality associated with COVID-19: the risk should not be down-played. Acta Obstet Gynecol Scand 2020;99:815-6. [PubMed] [CrossRef]

59. Roberton T, Carter ED, Chou VB, Stegmuller AR, Jackson BD, Tam Y, et al. Early estimates of the indirect effects of the COVID-19 pandemic on maternal and child mortality in lowincome and middle-income countries: a modelling study. Lancet Glob Health 2020;8:e901-e8. [PubMed] [CrossRef]

60. Martines RB, Bhatnagar J, Keating MK, Silva-Flannery L, Muehlenbachs A, GaryJ, et al. Notes from the field: evidence of Zika virus infection in brain and placental tissues from two congenitally infected newborns and two fetal losses -- Brazil, 2015. MMWR Morb Mortal Wkly Rep 2016;65:159-60. [PubMed] [CrossRef]

61. Kimberlin DW, Stagno S. Can SARS-CoV-2 infection be acquired in utero? More definitive evidence is needed. JAMA 2020;323:1788-9. [PubMed] [CrossRef]

62. Türk Neonatoloji Derneği. COVID-19 (SARS-CoV2) enfeksiyonu veya şüphesi olan yenidoğan bebeklere neonatal ve perinatal dönemde yaklaşım önerileri. v.2. [Internet] Ankara: Türk Neonatoloji Derneği. [updated 2020 Mar 3] Available from: http://www.neonatology.org.tr/media/2020/04/Untitledattachment-00052.pdf.

63. Penfield CA, Brubaker SG, Limaye MA, Lighter J, Ratner AJ, Thomas KM, et al. Detection of SARS-COV-2 in placental and fetal membrane samples. Am J Obstet Gynecol MFM 2020;100133. [PubMed] [CrossRef]

64. Shanes ED, Mithal LB, Otero S, Azad HA, Miller ES, Goldstein JA. Placental pathology in COVID-19. Am J Clin Pathol 2020;8;154:23-32. [PubMed] [CrossRef]

65. Baergen RN, Heller DS. Placental pathology in Covid-19 positive mothers: preliminary findings. Pediatr Dev Pathol 2020; 23:177-80. [PubMed] [CrossRef]

66. Hosier H, Farhadian S, Morotti RA, Deshmukh U, LuCulligan A, Campbell KH, et al. First case of placental infection with SARS-CoV-2. medRxiv 2020. doi:10.1101/ 2020.04.30.20083907 [CrossRef]

67. Alzamora MC, Paredes T, Caceres D, Webb CM, Valdez LM, La Rosa M. Severe COVID-19 during pregnancy and possible vertical transmission. Am J Perinatol 2020:37:861-5. [PubMed] [CrossRef] 
68. Dong L, Tian J, He S, Zhu C, Wang J, Liu C, et al. Possible vertical transmission of SARS-CoV-2 from an infected mother to her newborn. JAMA 2020;26;323:1846-8. [PubMed] [CrossRef]

69. Lokken EM, Walker CL, Delaney S, Kachikis A, Kretzer NM, Erickson A, et al. Clinical characteristics of 46 pregnant women with a SARS-CoV-2 infection in Washington State. Am J Obstet Gynecol 2020;S0002-9378(20)30558-5. [PubMed] [CrossRef]

70. ACOG. Novel Coronavirus 2019 (COVID-19). [Internet] Washington, DC: The American College of Obstetricians and Gynecologists. [cited 2020 Jun 5] Available from: https:// www.acog.org/clinical/clinical-guidance/practice-advisory/ articles/2020/03/novel-coronavirus-2019.

71. Poon LC, Yang H, Kapur A, Melamed N, Dao B, Divakar H, et al. Global interim guidance on coronavirus disease 2019 (COVID-19) during pregnancy and puerperium from FIGO and allied partners: information for healthcare professionals. Int J Gynaecol Obstet 2020;149:273-86. [PubMed] [CrossRef]

72. Chen D, Yang H, Cao Y, Cheng W, Duan T, Fan C, et al. Expert consensus for managing pregnant women and neonates born to mothers with suspected or confirmed novel coronavirus (COVID-19) infection. Int J Gynaecol Obstet 2020;149: 130-6. [PubMed] [CrossRef]

73. TPD. Gebelik, doğum ve lohusalık döneminde "Yeni Koronavirüs Enfeksiyonu 2019" (COVID-19) hakkında Türk Perinatoloji Derneği görüşü 2020. [Internet] Istanbul: Türk Perinatoloji Derneği. [cited 2020 Jun 5] Available from: http://www.perinatoloji.org.tr/gebelik-dogum-ve-lohusalikdoneminde-yeni-koronavirus-enfeksiyonu-2019-covid-19hakkinda-turk-perinatoloji-dernegi-gorusu

74. Patel SJ, Reede DL, Katz DS, Subramaniam R, Amorosa JK. Imaging the pregnant patient for nonobstetric conditions: algorithms and radiation dose considerations. Radiographics 2007;27:1705-22. [PubMed] [CrossRef]

75. Miller RW. Discussion: severe mental retardation and cancer among atomic bomb survivors exposed in utero. Teratology 1999;59:234-5. [PubMed] [CrossRef]

76. ACOG Committee on Obstetric Practice. Committee Opinion No. 723: Guidelines for diagnostic imaging during pregnancy and lactation. Obstet Gynecol 2017;130:e210-e6. [PubMed] [CrossRef]

77. ACR-SPR practice parameter for imaging pregnant or potentially pregnant adolescents and women with ionizing radiation 2018. [Internet] Reston, VA: American College of Radiology. [revised 2018] Available from: https://www.acr.org/-/media/ ACR/Files/Practice-Parameters/Pregnant-Pts.pdf

78. Tremblay E, Thérasse E, Thomassin-Naggara I, Trop I. Quality initiatives: guidelines for use of medical imaging during pregnancy and lactation. Radiographics 2012;32:897-911. [PubMed] [CrossRef]

79. Ai T, Yang Z, Hou H, Zhan C, Chen C, Lv W, et al. Correlation of chest CT and RT-PCR testing in Coronavirus Disease 2019 (COVID-19) in China: a report of 1014 cases. Radiology 2020;200642. [PubMed] [CrossRef]
80. Inchingolo R, Smargiassi A, Moro F, Buonsenso D, Salvi S, Del Giacomo $\mathrm{P}$, et al. The diagnosis of pneumonia in a pregnant woman with COVID-19 using maternal lung ultrasound. Am J Obstet Gynecol 2020;S0002-9378(20)30468-3. [PubMed] [CrossRef]

81. Dotters-Katz S. Hughes BL; The Society for Maternal-Fetal Medicine (SMFM). Coronavirus (COVID-19) and pregnancy: what maternal-fetal medicine subspecialists need to know. [Internet] Washington, DC: Society for Maternal-Fetal Medicine. [cited 2020 Jun 3] Available from: https://s3.amazonaws.com/cdn.smfm.org/media/2262/COVID19_PDF.pdf

82. ACOG. COVID-19 FAQs for Obstetrician-Gynecologists, Obstetrics. Washington, DC: American College of Obstetricians and Gynecologists. [cited 2020 Jun 3] Available from: https://www.acog.org/clinical-information/physicianfaqs/ covid-19-faqs-for-ob-gyns-obstetrics

83. Kwiatkowski S, Borowski D, Kajdy A, Poon LC, Rokita W, Wielgo SM. Why we should not stop giving aspirin to pregnant women during the COVID-19 pandemic. Ultrasound Obstet Gynecol 2020;55:841-3. [PubMed] [CrossRef]

84. Gavillet M, Rolnik DL, Hoffman MK, Panchaud A, Baud D. Should we stop aspirin prophylaxis in pregnant women diagnosed with COVID-19? Ultrasound Obstet Gynecol 2020;55: 843-4. [PubMed] [CrossRef]

85. Russell CD, Millar JE, Baillie JK. Clinical evidence does not support corticosteroid treatment for 2019-nCoV lung injury. Lancet 2020;395(10223):473-5. [PubMed] [CrossRef]

86. Koumoutsea EV, Vivanti AJ, Shehata N, Benachi A, Le Gouez A, Desconclois C, et al. COVID-19 and acute coagulopathy in pregnancy. Thromb Haemost 2020. doi:10.1111/jth.14856 [PubMed] [CrossRef]

87. WHO. Could \#ibuprofen worsen disease for people with \#COVID19? 2020. [Internet]. Geneva: World Health Organization. [cited 2020 Mar 18] Available from: https:// twitter.com/who/status/1240409217997189128

88. Mulangu S, Dodd LE, Davey RT, Tshiani Mbaya O, Proschan M, Mukadi D, et al.; PALM Consortium Study Team. A randomized, controlled trial of Ebola virus disease therapeutics. N Engl J Med 2019;381:2293-303. [PubMed] [CrossRef]

89. Anderson J, Schauer J, Bryant S, Graves CR. The use of convalescent plasma therapy and remdesivir in the successful management of a critically ill obstetric patient with novel coronavirus 2019 infection: a case report. Case Rep Womens Health 2020:e00221. [PubMed] [CrossRef]

90. Gao J, Tian Z, Yang X. Breakthrough: chloroquine phosphate has shown apparent efficacy in treatment of COVID-19 associated pneumonia in clinical studies. Biosci Trends 2020;14: 72-3. [PubMed] [CrossRef]

91. Liu F, Xu A, Zhang Y, Xuan W, Yan T, Pan K, et al. Patients of COVID-19 may benefit from sustained lopinavir-combined regimen and the increase of eosinophil may predict the outcome of COVID-19 progression. Int J Infect Dis 2020;12; 95:183-91. [PubMed] [CrossRef] 
92. Tookey PA, Thorne C, van Wyk J, Norton M. Maternal and foetal outcomes among 4118 women with HIV infection treated with lopinavir/ritonavir during pregnancy: analysis of population-based surveillance data from the national study of HIV in pregnancy and childhood in the United Kingdom and Ireland. BMC Infect Dis 2016;16:65. [PubMed] [CrossRef]

93. Zhou F, Yu T, Du R, Fan G, Liu Y, Liu Z, et al. Clinical course and risk factors for mortality of adult inpatients with COVID-19 in Wuhan, China: a retrospective cohort study. Lancet 2020;395(10229):1054-62. [PubMed] [CrossRef]

94. Metlay JP, Waterer GW, Long AC, Anzueto A, Brozek J, Crothers K, et al. Diagnosis and treatment of adults with community-acquired pneumonia. An official clinical practice guideline of the American Thoracic Society and Infectious Diseases Society of America. Am J Respir Crit Care Med 2019; 200:e45-e67. [PubMed] [CrossRef]

95. Wu Y, Liu C, Dong L, Zhang C, Chen Y, Liu J, et al. Coronavirus disease 2019 among pregnant Chinese women: Case series data on the safety of vaginal birth and breastfeeding. BJOG 2020. doi:10.1111/1471-0528.16276 [PubMed] [CrossRef]

96. Mehta H, Ivanovic S, Cronin A, VanBrunt L, Mistry N, Miller $\mathrm{R}$, et al. Novel coronavirus-related acute respiratory distress syndrome in a patient with twin pregnancy: a case report. Case Rep Womens Health 2020:e00220. [PubMed] [CrossRef]

97. Cooke WR, Billett A, Gleeson S, Jacques A, Place K, Siddall J, et al. SARS-CoV-2 infection in very preterm pregnancy: experiences from two cases. Eur J Obstet Gynecol Reprod Biol 2020;250:259-60. [PubMed] [CrossRef]

98. WHO. MERS situation update, January 2020. [Internet]. Geneva: World Health Organization. [updated 2020 Jan] Available from: http://www.emro.who.int/pandemic-epidemicdiseases/mers-cov/mers-situation-update-january-2020.html

99. Spychalski P, Blazynska-Spychalska A, Kobiela J. Estimating case fatality rates of COVID-19. Lancet Infect Dis 2020: S1473-3099(20)30246-2. [PubMed] [CrossRef]

100. Basu A. Estimating the infection fatality rate among symptomatic COVID-19 cases in the United States. Health Aff (Millwood) 2020:101377hlthaff202000455. [PubMed] [CrossRef]

101. Grasselli G, Pesenti A, Cecconi M. Critical care utilization for the COVID-19 outbreak in Lombardy, Italy: early experience and forecast during an emergency response. JAMA 2020;323:1545-6. [PubMed] [CrossRef]
102. Livingston E, Bucher K. Coronavirus Disease 2019 (COVID19) in Italy. JAMA 2020;323:1335. [PubMed] [CrossRef]

103. Elshafeey F, Magdi R, Hindi N, Elshebiny M, Farrag N, Mahdy S, et al. A systematic scoping review of COVID-19 during pregnancy and childbirth. Int J Gynaecol Obstet 2020;150:47-52. [PubMed] [CrossRef]

104. Ferrazzi E, Frigerio L, Savasi V, Vergani P, Prefumo F, Barresi S, et al. Vaginal delivery in SARS-CoV-2 infected pregnant women in Northern Italy: a retrospective analysis. BJOG 2020;10.1111/1471-0528.16278. [PubMed] [CrossRef]

105. Patane L, Morotti D, Giunta MR, Sigismondi C, Piccoli MG, Frigerio L, et al. Vertical transmission of COVID-19: SARS-CoV-2 RNA on the fetal side of the placenta in pregnancies with COVID-19 positive mothers and neonates at birth. Am J Obstet Gynecol MFM 2020;100145. [PubMed] [CrossRef]

106. Zeng H, Xu C, Fan J, Tang Y, Deng Q, Zhang W, et al. Antibodies in infants born to mothers with COVID-19 pneumonia. JAMA 2020;323:1848-9. [PubMed] [CrossRef]

107. Wang S, Guo L, Chen L, Liu W, Cao Y, Zhang J, et al. A case report of neonatal COVID-19 infection in China. Clin Infect Dis 2020;ciaa225. [PubMed] [CrossRef]

108. Zeng L, Xia S, Yuan W, Yan K, Xiao F, Shao J, et al. Neonatal early-onset infection with SARS-CoV-2 in 33 neonates born to mothers with COVID-19 in Wuhan, China. JAMA Pediatr 2020;e200878. [PubMed] [CrossRef]

109. Yu N, Li W, Kang Q, Xiong Z, Wang S, Lin X, et al. Clinical features and obstetric and neonatal outcomes of pregnant patients with COVID-19 in Wuhan, China: a retrospective, single-centre, descriptive study. Lancet Infect Dis 2020;20: 559-64. [PubMed] [CrossRef]

110. Yang H, Hu B, Zhan S, Yang LY, Xiong G. Effects of SARS$\mathrm{CoV}-2$ infection on pregnant women and their infants: a retrospective study in Wuhan, China. Arch Pathol Lab Med 2020. doi:10.5858/arpa.2020-0232-SA [PubMed] [CrossRef]

111. Carosso A, Cosma S, Borella F, Marozio L, Coscia A, Ghisetti V, et al. Pre-labor anorectal swab for SARS-CoV-2 in COVID-19 pregnant patients: is it time to think about it? Eur J Obstet Gynecol Reprod Biol 2020;249:98-9. [PubMed] [CrossRef]

112. Hegewald MJ, Crapo RO. Respiratory physiology in pregnancy. Clin Chest Med 2011;32:1-13. [PubMed] [CrossRef]

Bu makalenin kullanım izni Creative Commons Attribution-NoCommercial-NoDerivs 3.0 Unported (CC BY-NC-ND3.0) lisansı aracılı̆̆ılya bedelsiz sunulmaktadir. / This work is licensed under the Creative Commons Attribution-NonCommercial-NoDerivs 3.0 Unported (CC BY-NC-ND3.0) License. To view a copy of this license, visit http://creativecommons.org/licenses/by-nc-nd/3.0/ or send a letter to Creative Commons, PO Box 1866, Mountain View, CA 94042, USA. 